\title{
Sosyal Medya ve Toplumda Değişen Estetik İşlem Yaptırma AIgısı
}

Gül Dilek Türk, Adnan Menderes Üniversitesi, İletişim Fakültesi, Dr., guldilekturk@yahoo.com, ORCID: 0000-0002-8610-7153

Serkan Bayrakc1, Marmara Üniversitesi, İletişim Fakültesi, serkan.bayrakci@marmara.edu.tr, ORCID: 0000-0002-3817-1927

$\ddot{O Z Z}$

Sosyal medyanın yayginlaşması ile birlikte bilgiye her yerden ve herkes tarafindan ulaşılmaya başlanmış; bilginin kolayca dolaşıma girmesi ve yaygınlaşmasıyla birlikte sosyal medya öncesi dönemde var olan pek çok tabu da yıkılmaya başlamıştır. Daha önce ulaşılmaz ve sadece belli sosyo-ekonomik sinıflara ait olduğ u düşünülen pek çok şeyde sosyal medyanın gücünün keşfiyle birlikte bir tür havastan avama yayılma formunu almıştır. Estetik işlem uygulama ve uygulatma da yine sosyal medyanın yayginlaşmasıyla birlikte form değiştirerek belli sosyo-ekonomik sinıfların yaptırdığı bir tedavi olmaktan çıkıp sıradan bir insanın da öğle yemeği arasında gidip yaptırdığı bir işleme dönüşmüş, bir ihtiyaç halini almıştır.

Kullanıcılar sosyal medyada plastik cerrahlarm, estetisyenlerin tanttmlar vasıtasıyla bu işlemlerin ve estetik işlem uygulayıcıların ulaşılabilir olduğunu fark etmiş, bu işlemi yaptıran kendi gibi insanları gördükçe de bu işlemlerin bir ihtiyaç olduğuna hükmetmiştir. Bu bağlamda sosyal medyanın toplumdaki estetik işlem yaptırtma algısı üzerindeki etkisini ölçmek üzere sosyal medya hesaplarında çeşitli estetik sayfaların takip eden, farklı demografik sınıflardan 116 kişiyle online anket çalışması yapılmıştır.

Anahtar $\quad$ : $\quad$ Estetik, Sosyal Medya, Plastik Cerrahi, Botoks, Dolgu, Gençlik, Güzellik, Kişilerarası Kelimeler iletişim

\section{Social Media and Perception of Changing Aesthetic Operation in Society}

ABSTRACT

With the spread of social media, information has started to be accessed from everywhere and by everyone and many taboos that existed in the pre-social media period began to collapse as the information was easily circulated and spread. With the discovery of the power of social media in many things previously thought to be inaccessible and only belonging to certain socio-economic classes, it has taken the form of a kind of air-to-air spread. Aesthetic procedure application and application also changed form with the spread of social media and changed from being a treatment made by certain socio-economic classes to a process that an ordinary person had to go between lunch and became a need.

Users have realized that these procedures and aesthetic procedure practitioners are accessible through the introduction of plastic surgeons, estheticians on social media, 
as he saw people like him who made this transaction, he decided that these transactions were a need.In this context, an online survey was conducted with 116 people following various aesthetic pages in social media accounts, from different demographic classes to measure the effect of social media on perception of aesthetic procedure in society.

\section{Keywords : Aesthetics, Social Media, Plastic Surgery, Botox, Filling, Youth, Beauty, Interpersonal Communication} Gíriş

Estetik, Antik Yunan'da "aisthanomai" kelimesinden türetilmiş olup algılamak anlamına gelmektedir. Algılama zihinsel bir süreç olup insanın 5 duyusuyla edindiği verileri mantıksal süzgeçlerden geçirerek sonuçlara ulaşmaktadır. Bu nedenle de estetik duyu bilimi olarak da kabul edilmektedir (Yetişken, 1998; Arat, 2006). Estetik Leonardo Da vinci'nin altın oranı ve Fibonacci dizimiyle oranı ölçüsünde bir şeyin ideal olup olmadığı yönündeki hükmüdür(Yetişken, 1998; Lin \& Thomas, 2002; Seeley, 2006). Bu bağlamda estetik güzel ve ideal olanın felsefesidir. Zihin gördüğü imgeleri algıladığında onun estetik ya da güzel görünüp görünmediğine de karar kılmaktadır. Bu mekanizma oluşurken elbette aile, çevre, kültür ve medya (bkz. Aktaş, 2014; Köse, 2011; Gencel \& Mutlu 2000; Oktayş 2009; Odabaş, 2008) oldukça etkili olup kişinin güzellik ve estetik algısının da temelini oluşturmaktadır. Bu nedenle her dönem kadın güzelliği ve bedenine yönelik olarak güzellik ve estetik algısı değişim göstermektedir. Bu bağlamda toplumsal ya da dönemsel güzellik aldısı ideal bir beden ve güzellik estetik anlayışını da insanlara dayatarak ona uygun bir forma gelmeye onları zorlamaktadır. Bu nedenle estetik işlemler sosyal medyanın da etkisiyle kolaylıkla ulaşılabilir olduğu algısının yayılmasıyla birlikte toplumda her kesimden insan tarafından tüketilebilir ve ulaşılabilir bir ihtiyaç halini almıştır.

"Literatürde estetik ameliyatı olanların; rekonstruktif (bozulan, işlevini yitiren yeri onarma) ameliyat olanlara göre, bilgi kaynağı olarak internet, basın ve televizyonu daha fazla oranda kullandığı belirtilmektedir" (Fındıkçığlu vd., 2005; Aktaş, 2014: 191).

Tüketim kültürü sosyal medya ile birlikte gittikçe güçlenmekte olup kusursuz beden algısı yoluyla estetik ameliyatları ve işlemleri bir ihtiyaç haline getirmiştir. Sadece kadın değil artık erkek bedeninin de belki de hiçbir dönemde olmadığı kadar ön plana çıktığı sosyal medya çağında Instagram, Facebook gibi platformlar üzerinden herkes imajlarıla var olmakta, photoshop gibi düzenleme programlarıyla görüntülerini düzelterek her coğrafyadan insanlarla adeta ünlü biriymişçesine fotoğraflarını paylaşmakta ve karşılığında beğeniler alarak görünüşüne bedel biçmektedir. Lacan'a göre "her birimiz için belirleyici olanın kendimizi nasıl gördügümüz veya görmek istediğimiz değil, kuiltürel nazar tarafından nasıl algılandığımızdır" (Silverman, 2006: 37). Her ne kadar sosyal medyada sadece kelimeler ve 
imajlarla yer alınsa da insan bedeniyle, düşünceleriyle ve ruhuyla bir bütün olduğundan bu kusursuzluğu fiziki dünyaya ve fiziki bedenine de taşımak istemektedir. Sosyal medyayla birlikte artık kadınlar kadar erkekler de bedenine ve görüntüsüne odaklanmaktadır. Estetik işlem yaptırma ihtiyacı duyan erkek hastaların sayısı da her geçen gün artmaktadır.

"Tuiketimde sadece biyolojik bir beden anlayışının değil, aynı zamanda simgesel olarak üretilmiş bir "sosyal beden" anlayışının geçerli kılınmasıdır. Buna göre, simgesel olarak kurulmuş sosyal beden, aynı zamanda kendini meşrulaştırmış bir iktidar tarafından "yönetilen" bir bedendir. İhtiyaçları, görünümleri, gerek içeriksel, gerekse biçimsel olarak sahip olacağı göstergeler ve imajları dönemsel olarak ön belirlenmiş bedenin açıkça bir meta değeri taşıyan niteliğiyle, artık etkin düşünme ve eylemde bulunmanın özgür alanı içinde tasavvur edilmesi imkânsızdır" (Köse, 2011: 77).

Baudrillard'ın "anlamı yitirme pahasına kendi görüntüsüne kapılmanın kışkırtıcılığı" (2001: 75) ifadesiyle aslında biricikleşmeye çalışırken aynılaşan insanların öznelliklerini yitirerek birer metaya dönüşmesini de vurgulamaktadır. Baudrillard "makyaj da yüzü geçersiz kılmanın bir yoludur; daha güzel gözlerle gözler geçersiz kılınır; daha kusursuz dudaklarla dudaklar ortadan kaldırılır" (2001: 116) diyerek bu aynılaşmanın ve biricik olanın yok edilişinin altını çizmektedir. Sosyal medya bir anda sıradan bir kişiyi networkü çapında adeta sahneye çıkarmakta ve onu paylaşımları ölçüsünde yıldızlaştırmaktadır. Bu büyüye kapılan kullanıcılar sahte kendilikler ve sahte bedenler üretmek yoluyla aldıkları beğeni, takdir ve ilginin devam etmesini sağlamaya çalışmaktadır.

Yaygınlaşan ve kabul gören dönemin beden ve estetik alg1sı ile bireyler ötekilerden onay, beğeni, takdir almak uğruna bedenini kusursuzlaştırma yoluna gitmekte böylelikle kendini toplumsal değer ölçütleriyle değerlendirerek daha genç, daha güzel, daha çekici görmekte başkalarını da bu ölçülere göre anlamlandırmaktadır. Köse'nin "sosyal beden" olarak kavramsallaştırdığı bu kusursuz beden ve estetik algısı bireyin modernizmle birlikte bağlamından, özünden kopması ve ruhsal olarak yaşadığı boşluğu bedenini kusursuzlaştırma yoluyla doldurmaya çalışmasına neden olmaktadır. Kusursuz beden algısı "geçerli bir sosyal beden kurgusuyla güvence altına alınmış bir kendilik algılaması, arzulu varlığın hissettiği yoksunlukların telafi edilmesine hizmet etmektedir" (Köse, 2011: 78; Odabaş, 2008).

Sosyal medya anaakım medyayla zaten empoze edilen beden algısının artık her kesim insan tarafından ulaşılabilir, başarılabilir bir form olduğunu göstermiştir. Sosyal medya öncesi dönemde tanıtım eksikliği, toplumsal tabular, dini ya da ekonomik kaygılar ya da mahalle baskısı nedeniyle uzak durulan estetik operasyonlar ve işlemler sosyal medya ile birlikte popülerleşmiş ekonomik olarak da ulaşılabilir ve herkes tarafından yaptırılabilir olduğu algısı toplumca benimsenmiştir. Artık ergenlik çağındaki çocuklardan 70-80 yaşlarındaki insanlara kadar ev hanımından doktoruna, işçisinden esnafına her kesimden kişinin yaptırabildiği, ulaşabildiği ve yadırganma oranının gittikçe azaldığı bir işlem halini alııştır. Sosyal medya 
ile empoze edilen kusursuz bedene ulaşma arzusu insanları bu işlemleri yaptırmaya ve bir ihtiyaç olarak görmeye itmiştir.

Madde dolayısyla beden odaklı tüketim kültürü de bedenleri metalaştırarak onları bir tüketim nesnesi, bir sermaye haline getirmiş, beden ne kadar kusursuzsa o kadar beğenilen, takdir edilen ve imrenilen bir nesneye dönüşmüştür. Ancak bu durum standart bir beden algısının oluşmasına ve farklılaşarak özel olmak isteyen kişilerin birbirine benzemeye başlamasına da neden olmuştur. Foucault'un bio-politika (2003: 31) diye adlandırdığı bu tüketim kültürü tarafından empoze edilen standart beden formuyla kişilere bu beden biçimine sahip olmaları durumunda sahip olacakları biriciklik arzusu satarak herkesi ve her şeyi standartlaştırmakta ve aynılaştırmaktadır. Levinas'a göre, beden, özünde "ötekinin aynıya indirgenmesi" sürecine işaret eden bir egobilimin (Batı felsefesi'nin) kendisine sistemli olarak bir tür "ontolojik emperyalizm" uyguladığı şeydir (aktaran Köse, 2011: 79).

Kusursuzlaşan bedenlerini sosyal medyadan paylaşan kullanıcılar diğer kullanıcılar üzserinde de bu bio-politikayı uygulayan bir iktidar aracına dönüşmektedir. Kendi bedenleri üzerinden ötekileri tanımlamakta ve aldıkları beğenilerle de bu bio-politika uygulayıcının iktidarını güçlendirmektedir. Çünkü , “beğeni, bazıları için benzerlik sembolüyken, diğerleri için bedenlerinde taşıdıkları damgayı (stigma) gösterir...kişinin sosyal değeri, kendi dil ürünü ve beden değeriyle birleşerek oluşur" (Işık 1998: 140-141).

Sosyal medya da tamamen imajlar üzerinde kurgulanan ve sembollerle var olunan bir alan olarak Bauman'ın "Tuiketimci ortam" olarak tanımladığı dijital bir alandır ve "bedenin kendisini dış uyarıcılardaki zengin ve daha zengin deneyim potansiyeline olabildiğince açmasını ve bedenin uygunluğunun bu uyarıcıları emme yetisi ile ölçuilmesini zorunlu kılmaktadır" (2001: 162). Çünkü dijital platformda imajlarıyla var olan ve kendilerine sunulan standart sembolik bedene ulaşma arzusuyla bedenlerini metalaştıran kullanıcılara ötekilerden gelen beğeniler yoluyla bir değer bir bedel biçmektedir. Ne kladar çok beğeni o kadar çok değer algısı yarattığından daha değerli hissetmek için daha çok beğeni almaya bunun için de kusurlardan kurtulmaya yönelik daha güçlü dürtüler ve arzular duymaya başlamaktadır. Işık (2008), “Estetize edilmiş beden” kavramı bu standartlaştırılmış kusursuz beden algısını tanımlamakta ve kullanıcılar üzerinde estetikleşme mecburiyeti yönünde bir baskı yaratmaktadir.

Işık'ın (2008), “tüm dünyada bir hayalet dolaşmaktadır, 'ideal beden' hayaleti" ifadesi de durumu net bir şekilde ortaya koymaktadır. İdeal kusursuz bedene ulaşma arzusu kişileri büyük harcamalar yapmaya hatta bedenlerini estetize etmek üzere ciddi operasyonlar olmaya zorlamaktadır. Artık sadece kadın bedeni değil erkek bedeni de metalaşmakta karşı cins tarafından arzulanırken hem cinsleri tarafından gıptayla bakılan birer arzu nesnesine 
dönüşmeyi amaçlayan bireyler "beğenilen, koklanan çiçekler olmak adına muithiş bir terör; kendinden kaçış, kendinden utanma, kuilt bedenlerle ümitsiz bir yarış, aşırı stres, güzellik ürünlerinin yan etkileri, solaryumlar, bedeni tıbbın teneşir tahtasına yatırma, botokslar, silikonlar, yă̆ aldırmalar, eklemeler, çıkarmalar, uzatmalar, kısaltmalar, vs. yani saçtan tırnağa estetik, yapboz tahtasına dönüşen bir nesne-beden" dir (Işı1k, 2008).

Köse bu işlemlerin Baudrillard'ın “başkalığın estetik cerrahisi” (2001) işleminden başka bir şey olmadığını “özünde, öznelliğin yitimini ve başkası olma kolaycılığını simgeleyen bu deyim, her tür sosyal beden kurgusunun bireyi 'kendisi olma sorumluluğundan' kurtaran tuketimci bir felsefeye hizmet etmekte" (Köse, 2011: 86) olduğunu belirtmektedir. Ana akım medyadan daha ikna edici ve daha yayılmacı sosyal medya ideal, kusursuz, estetik beden algısını zorunluluk gibi çocuğuktan yaşlıya, kadından erkeğe yaymakta daima genç, güzel, estetik olma algısını dini bir kaide gibi bilinçaltına işlemektedir.

Sosyal medya, Instagram ve selfy ile yayılan estetik görünme çllgınlığı ergenlik çağındaki gençlerde de etkili olmaktadır. Gençlerde bu ideal kusursuz bedene ulaşmak üzere kilo memnuniyetsizliği yaratmakta ve buna bağlı yeme bozukluğuna neden olarak diyet hap1 kullanma, ağır egzersiz yapma, anoreksiya nervoza, bulimia nervoza gibi rahatsızlıklar yaşamalarına sebep olmaktadır (Örsel vd., 2004; Atik \& Örten, 2008; Tiggemann \& Miller, 2010). Ancak gittikçe artan estetik yaptırma modası sadece ergenlerde değil aksine her yaş ve her meslekten insanı içeren geniş bir yelpazede kabul görmeye başlamıştır. Sarı, yaptığı araştırmada artık üniversite mezunlarından okuma yazma bilmeyenlere kadar geniş bir kesimin estetik işlem ya da operasyon yaptırmak üzere estetik kliniklerine gittiğini ortaya koymuştur (Sarı, 2016: 78-79). 30 Eylül 2019 tarihli Show Ana Haber'de de selfylerde güzel çıkma arzusuyla burun estetiği (rinoplasti) yaptırma yaşının 14-16 yaşa kadar düştügüüü dile getirilmiştir (Show TV https://www.youtube.com/watch?v=QUUmHyQVztc). Akademik Tip dergisi "Plastic and Reconstructive ve Surgery"' de yayınlanan bir araştırmada, plastik cerrahi hastalarından beşte dördünün, kozmetik cerrahi arayışlarında televizyon programlarından etkilendikleri belirtilmektedir (Twenge \& Campbell, 2010: 216 akt. Arasl1, 2017: 66). Araslı, "estetik cerrahi, yalnızca tıp söylemi ve pratiğinin sınırlarında hızlı bir şekilde gelişen bir uzmanlık alanı olmaktan ziyade, bedenle ilgili deneyim, bedenler arası algı/sınır/ karşılaşmaları dönüştư̈ren beden politikalarından biridir" (Araslı,2017: 64) diyerek estetik işlemler yoluyla kişilerin zihinnlerinde yaratılan ideal estetik beden formu yaratıldığını ve bu ideal bedene ulaşma arzusunu da kişiler, artık ulaşılabilirliği kolay olan estetik işlemlerle gerçekleştirme imkanı bulmaktadır. Bu estetik beden algısı sosyal medya tanıtımları vasıtasıyla büyük bir sektöre dönüşmüş olup, özellikle Türkiye, en çok estetik operasyon yapılan ülkeler sıralamasında yılda 50 bin estetik operasyonla 9. Sirada yer almaktadır (Sabah, 2 Mayıs 2017).

\section{Araştırmanın Yöntem ve Örneklemi}


Sosyal medya ve estetik ilişkisini ölçmeye yönelik yapılan bu çalışmada nicel araştırma yöntemlerinden tarama araştırması benimsenmiş, veri toplama aracı olarak ise çevrimiçi anket tekniği kullanılmıştır. Araştırmanın evrenini sosyal medya kullanan ve estetik yaptırmış, yaptırmayı düşünen ya da estetik hakkında bilgisi olan herkes oluşturmaktadır. Örneklemi araştırmanın evrenini yansıtacak farklı mesleklerde, farklı eğitim düzeylerinde, farklı gelir durumlarında sosyal medya kullanan ve sosyal medya hesaplarında çeşitli estetik sayfalarını takip eden 116 gönüllü katılımcı oluşturmaktadır. Araştırma soruları; yapılan literatür çalışması ardından araştırmacılar tarafından geliştirilmiştir. 18 madde 5'li Likert tipinde (1=Kesinlikle Katılmıyorum, 2=Katılmıyorum, 3=Kararsızım, 4=Katılıyorum, 5=Kesinlikle Katılıyorum) hazırlanmıştır. Ayrıca katılımcıların demografik yapılarını ve gündelik pratiklerini belirlemeye yönelik maddeler içermektedir. Çevrimiçi anket tekniğiyle toplanan veriler SPSS 21 (The Statistical Package for the Social Sciences) yazilımda analiz edilerek, sonuçlar değerlendirilmiştir.

\section{Bulgu ve Sonuçlar}

Estetikle ilgili sosyal medya hesaplarından en az bir tanesini takip eden katılımcıların yaş ortalaması 29, modu ise 21'dir. En az 17 yaşında ve en çok 55 yaşında katılımcı vardır. Katılımcıların cinsiyet ve medeni durumları Tablo 1.'de gösterilmiştir.

Yapılan araştırmanın verileri 100 kadın $(\% 86,2)$ ve 16 erkek $(\% 13,8)$ olmak üzere 116 kişilik bir örneklemden elde edilmiştir. Katılımcılardan 41'i $(\% 35,2) 17$ ilâ 22 yaş aralığında, 16'sı $(\% 13,8)$ 23-27 yaş aralığında ve 14'sı (\%12,1) 28-32 yaş aralığında, 31'i (\%26,7) 33-38 yaş aralığında, 7'si (\%6,1) 39-43 yaş aralığında, 7'si (\%6,1) 44 ve üzeri yaş aralığındadır. Katılımcıların büyük çoğunluğu lisans derecesinde $(n=72, \% 62,1)$. Medeni durumlarına bakıldığında katılımcıların büyük çoğunluğunun bekâr $(n=74, \% 63,8)$ olduğu görülmektedir. Gelir düzeylerine bakıldığında katılımcıların büyük çoğunluğunun 0-2000 TL (n=64, \%55,2) olduğu görülmektedir. Katılımcılara ait demografik değişkenlerin sayı ve yüzde dağılımları Tablo 1.'de gösterilmiştir:

Tablo.1 Katılımcılara Ait Demografik Değişkenlerin Sayı ve Yüzde Dağılımları

\begin{tabular}{|l|l|l|l|}
\hline Değişkenler & Gruplar & Sayı (n) & Yüzde (\%) \\
\hline \multirow{4}{*}{ Cinsiyet } & Kadın & 100 & 86,2 \\
\cline { 2 - 4 } & Erkek & 16 & 13,8 \\
\hline \multirow{4}{*}{ Yaş } & $17-22$ & 41 & 35,2 \\
\cline { 2 - 4 } & $23-27$ & 16 & 13,8 \\
\cline { 2 - 4 } & $28-32$ & 14 & 12,1 \\
\cline { 2 - 4 } & $33-38$ & 31 & 26,7 \\
\cline { 2 - 4 } & $39-43$ & 7 & 6,1 \\
\cline { 2 - 4 } & 44 ve üzeri & 7 & 6,1 \\
\hline
\end{tabular}




\begin{tabular}{|l|l|l|l|}
\hline \multirow{5}{*}{ Eğitim durumu } & İlkokul & 2 & 1,7 \\
\cline { 2 - 4 } & Ortaokul & 3 & 2,6 \\
\cline { 2 - 4 } & Lise & 22 & 19,0 \\
\cline { 2 - 4 } & Lisans & 72 & 62,1 \\
\cline { 2 - 4 } & Lisansüstü & 17 & 14,7 \\
\hline \multirow{4}{*}{ Medeni durum } & Evli & 42 & 36,2 \\
\cline { 2 - 4 } & Bekâr & 74 & 63,8 \\
\hline \multirow{5}{*}{ Gelir düzeyi } & $0-2000$ TL arası & 64 & 55,2 \\
\cline { 2 - 4 } & $2001-4000$ TL arası & 20 & 17,2 \\
\cline { 2 - 4 } & $4001-6000$ TL arası & 22 & 4,3 \\
\cline { 2 - 4 } & $6001-8000$ TL arası & 5 & 100 \\
\cline { 2 - 4 } & 8001 Üstü TL arası & 5 & 416 \\
\hline Toplam & & 116 & \\
\hline
\end{tabular}

Katılımcıların sosyal medyaya olan ilgileri ve kullanım durumlarına yönelik bilgiler ise aşağıdaki gibidir:

Tablo 2. Katılımciların sosyal medya kullanım durumları

\begin{tabular}{|l|l|l|}
\hline Sosyal Medya Kullanımı & Frekans & Yüzde \\
\hline Günde 0-2 saat & 20 & 17,2 \\
\hline Günde 2-4 saat & 49 & 42,2 \\
\hline Günde 4-8 saat & 30 & 25,9 \\
\hline Günde 8-12 saat & 11 & 9,5 \\
\hline Günde 12 saat ve üzeri & 4 & 3,4 \\
\hline Haftada birkaç kez & 1 &, 9 \\
\hline Arada bir & 1 &, 9 \\
\hline Toplam & 116 & 100 \\
\hline
\end{tabular}

İkinci tablodan görülebileceği üzere katılımcıların neredeyse yarısına yakını $\% 42$ 'si günde 2 saat ile 4 saat arasında, \%26'sı ise günde 4-8 saat arasında sosyal medya kullanmaktadır. $\% 17,2$ 'si ise günde iki saate yakın kullanmaktadır. Toplamda ise katılımcıların \%95'i sosyal medyayı günlük kullanmaktadır.

Ankete katılanların meslekleri farklılık göstermektedir, katılımcıların mesleki dağılımları ise şu şekildedir:

Tablo 3. Katılımcıların Meslek Dağılımları

\begin{tabular}{|l|l|}
\hline Mesleği & Kişi Sayısı \\
\hline Akademisyen & 6 \\
\hline Çalışmıyor & 3 \\
\hline
\end{tabular}




\begin{tabular}{|l|l|}
\hline Ev hanımı & 8 \\
\hline İnsan Kaynakları & 3 \\
\hline Medya Sektörü & 9 \\
\hline Memur & 4 \\
\hline Mühendis & 4 \\
\hline Öğrenci & 42 \\
\hline Öğretmen & 18 \\
\hline Özel Sektör Çalışanı & 14 \\
\hline Sağlık Çalışanı & 3 \\
\hline Uzman Estetisyen & 1 \\
\hline Toplam & $\mathbf{1 1 5}$ \\
\hline
\end{tabular}

Üçüncü tablodan görülebileceği üzere araştırmaya 12 farklı meslekten bireyler katılmıştır. Katılımcıların büyük çoğunluğunu ( $n=42)$ öğrenciler oluşturmaktadır. Bunu öğretmen $(n=18)$ ve özel sektör çalışanları ( $n=14)$ izlemektedir. En düşük katılım ise uzman estetisyen $(n=1)$ grubuna aittir.

Katılımcıların aktif olarak kullanmış oldukları sosyal medya platformları Tablo 4'de verilmiştir.

Tablo 4. Aktif Kullanılan Sosyal Medya Platformları

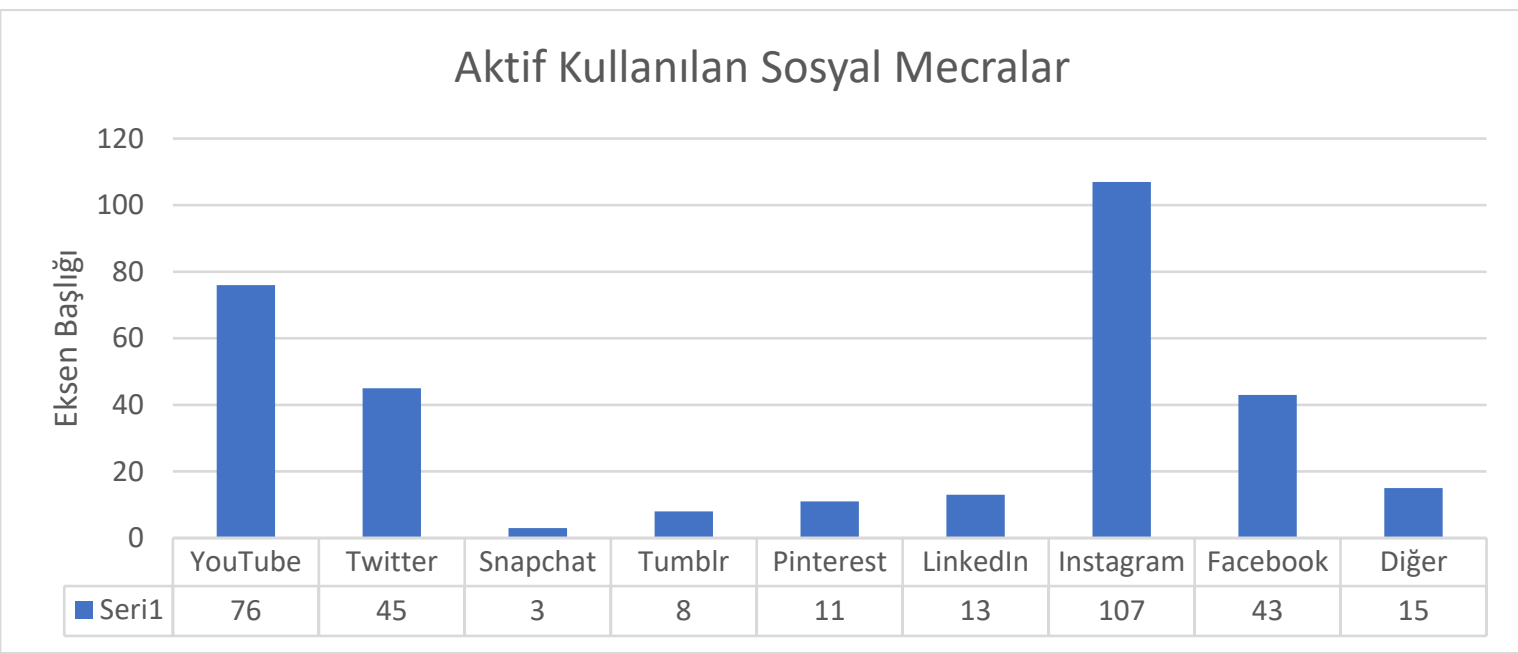

Katılımcların birden fazla sosyal medya platformunu aktif olarak kullandığı söylenebilir. Tabloya göre kullanıcıların sırasıyla en aktif olarak kullandıkları platformlar Instagram 107 kişi (\%92.2), Youtube 76 kişi (\%65.5), Twitter 45 kişi (\%38.8), Facebook 43 kişi $(37,1)^{\prime}$ dir. (Birden fazla seçeneğin işaretlenmiş olması yüzdelerin toplamının \%100'den farklı kılmaktadır. )

Çalışmaya katılanlara estetik işlem yaptırma kararı almalarında sosyal medyadan takip ettikleri ve etkilenecekleri kişilere dair veriler Tablo 5'de verilmiştir.

Tablo 5. Estetik İşlem Kararında Etkili Olabilecek Sosyal Medya Hesapları 


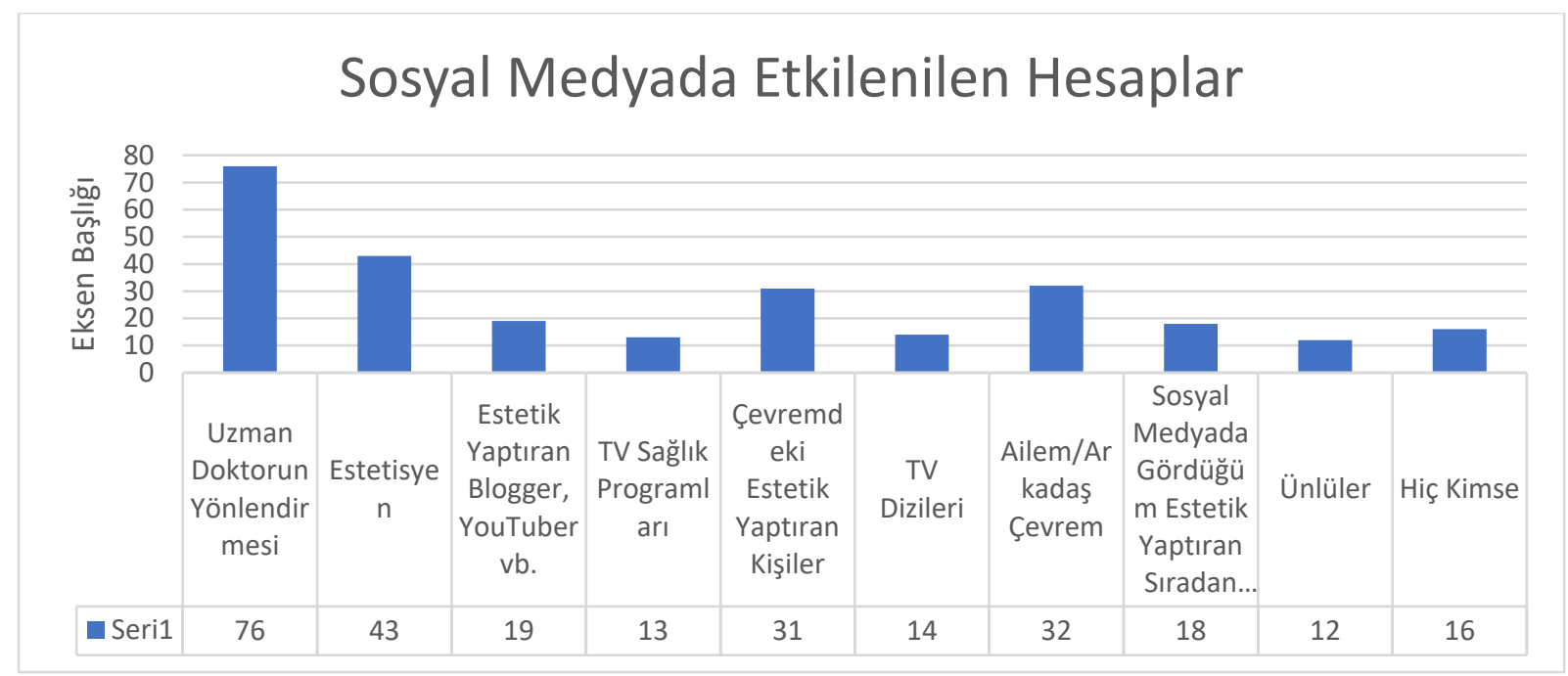

Katılımcıların estetik işlem yaptırma kararı bakımından sosyal medyadan etkilendiği hesaplara bakıldığında uzman doktorların yönlendirmesini işaretleyen 76 kişi (\%66.5) kişidir. Çevremde estetik yaptıranlar diyen 31 kişi (\%26.7), estetik yaptıran Blogger, YouTuber vb. diyen 19 kişi (\%16.3) ve sosyal medyada gördüğü estetik yaptıran sıradan insanlar diyen ise 18 kişi $(\% 15,6)$ bulunmaktadır. Katılımcılara estetik yaptırdıklarında ne hissedeceği sorulduğunda verilen cevaplar Tablo 6 'da verilmiştir.

Tablo 6. Estetik İşlem Yaptırınca Hissedilen Duygu

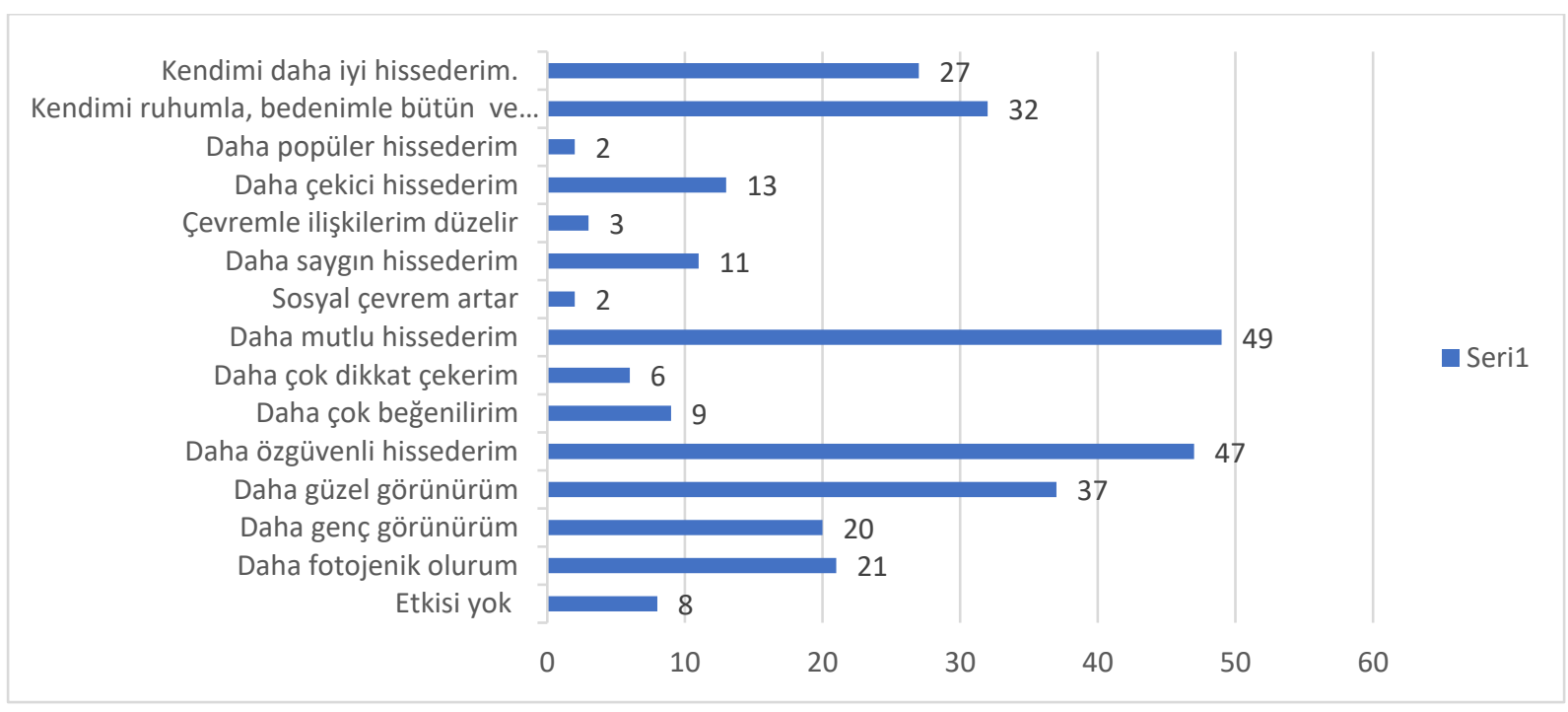

Katılımcıların estetik yaptırdığında kendini nasıl hissettikleri konusunda büyük çoğunluğu daha mutlu 49 kişi $(\% 47,6)$, daha özgüvenli 47 kişi $(\% 45,6)$ vardır. Daha güzel görünümlü 37 kişi $(\% 35,9)$, kendi ruhuyla ve bedeniyle bütünleşmiş 32 kişi $(\% 27,6)$, daha fotojenik 21 kişi $(\% 20,4)$ ve son olarak daha genç hissedeceğini belirten 20 kişi $(\% 19,4)$ bulunmaktadır. Katılımcıların yaptırmak istediği estetik işlemler Tablo 7'de verilmiştir. 
Tablo 7. İstenen Estetik İşlemler

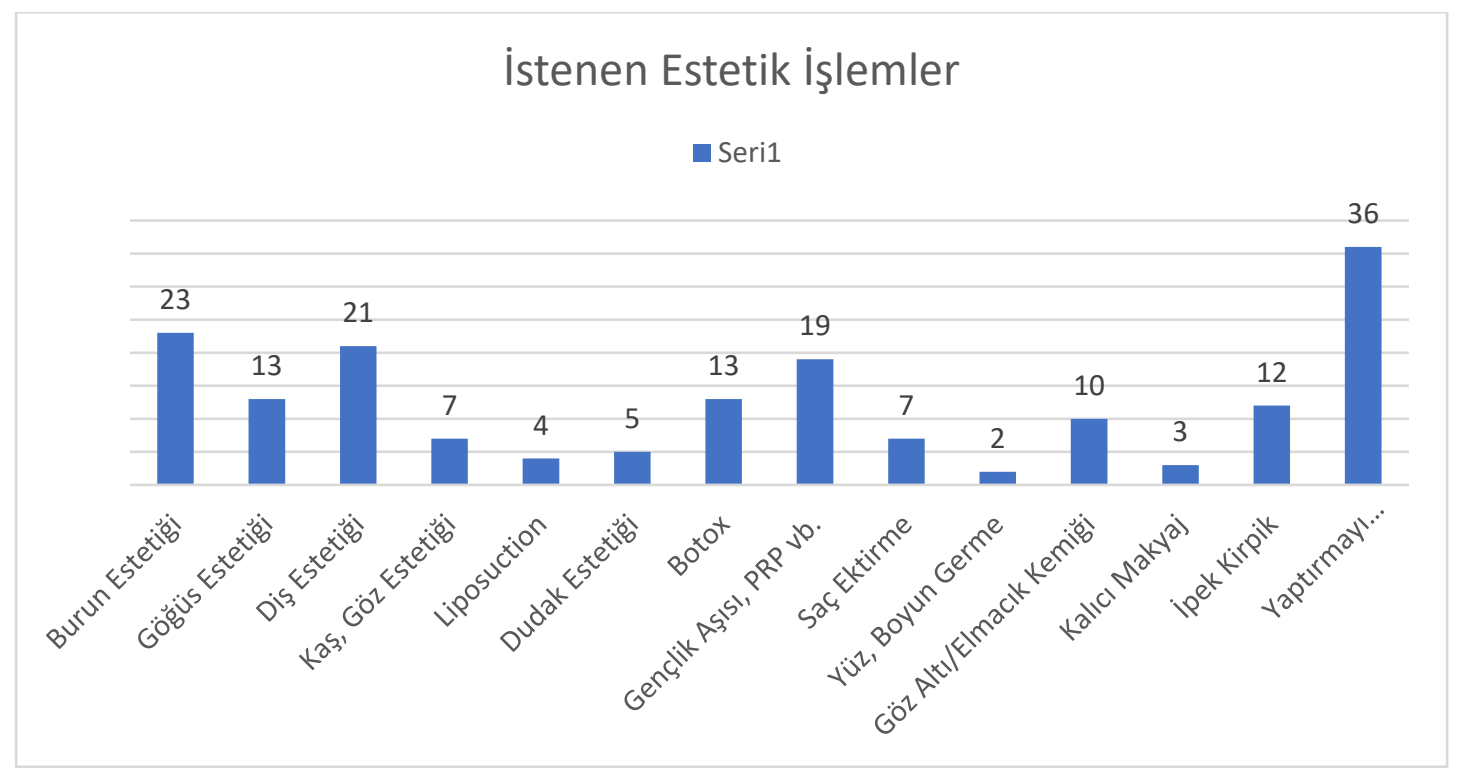

Katılımcıların yaptırmak istediği ya da yaptırmayı düşündüğü estetik işlemler sorulduğunda 23 kişi $(\% 19,8)$ burun estetiği, 21 kişi $(\% 18,1)$ kişi ve 19 kişi $(\% 16,4)$ ise gençlik aşısı yaptırmak istediğini ifade ederken, 36 kişi (\%31) ise herhangi bir estetik işlem yaptırmak istemediğini ifade etmiştir.

Araştırmacılar tarafından geliştirilen anket soruları faktör analizine sokulmuştur. Faktörler arasında anlamlı bir ilişki olmaması nedeniyle faktör analizinde Varimax tekniği kullanılmıştır. Herhangi bir faktör yükünde olmayan, faktör yükü 0,3 altında olan ya da birbirine yakın değerlerle birkaç faktörün altında olan maddeler çıkarılmıştır. Ortaya çıkan faktörler ve yükleri sırasıyla Tablo 9.'da verilmiştir:

Tablo 9. Faktörler ve Yükleri

\begin{tabular}{|c|c|c|c|c|c|}
\hline \multicolumn{2}{|c|}{ Maddeler } & $\begin{array}{l}\text { Boyut } \\
-1\end{array}$ & $\begin{array}{l}\text { Boyut } \\
-2\end{array}$ & $\begin{array}{l}\text { Boyut } \\
-3\end{array}$ & $\begin{array}{l}\text { Boyut } \\
-4\end{array}$ \\
\hline M5 & $\begin{array}{l}\text { Sosyal medya yoluyla estetik cerrahi hakkında } \\
\text { yanlış bilgilere sahip olduğumu fark ettim. }\end{array}$ & .722 & & & \\
\hline M6 & $\begin{array}{l}\text { Sosyal medya ile birlikte estetik işlemlerin bir } \\
\text { ihtiyaç olduğunu düşünmeye başladım. }\end{array}$ & .676 & & & \\
\hline M14 & $\begin{array}{l}\text { Sosyal medyada fiziksel kusurlarımı gidermek, } \\
\text { kusursuz ve daha estetik görünmek zorunda } \\
\text { olduğumu hissediyorum }\end{array}$ & .662 & & & \\
\hline M3 & $\begin{array}{l}\text { Sosyal medya kullanmaya başladıktan sonra } \\
\text { kendimi yeterince güzel ve çekici bulmamaya } \\
\text { başladım. }\end{array}$ & .661 & & & \\
\hline
\end{tabular}




\begin{tabular}{|c|c|c|c|c|c|}
\hline M11 & $\begin{array}{l}\text { Sosyal medya kullanmadan önce estetik işlemlere } \\
\text { ve estetik işlem yaptıranlara yönelik ön yargılarım } \\
\text { vardı. }\end{array}$ & .642 & & & \\
\hline M4 & $\begin{array}{l}\text { Sosyal medyada gördüğüm sıradan insanların da } \\
\text { estetik işlem yaptırması beni cesaretlendirdi }\end{array}$ & .636 & & .474 & \\
\hline M8 & $\begin{array}{l}\text { Sosyal medya kullanmadan önce sadece } \\
\text { zenginlerin ve ünlülerin estetik yaptırabileceğini } \\
\text { düşünüyordum. }\end{array}$ & .631 & & .448 & \\
\hline M7 & $\begin{array}{l}\text { Sosyal medya kullanmaya başladıktan sonra } \\
\text { estetik işlem yaptırmaya karar verdim. }\end{array}$ & .566 & & & \\
\hline M16 & $\begin{array}{l}\text { Sosyal medya kullanmadan önce yaptırdığım } \\
\text { estetik işlemleri çevremden gizlemeyi tercih } \\
\text { ederdim }\end{array}$ & & .897 & & \\
\hline M17 & $\begin{array}{l}\text { Sosyal medya kullanmadan önce estetik } \\
\text { operasyonların günah olduğunu düşünürdüm }\end{array}$ & & .837 & & \\
\hline M15 & $\begin{array}{l}\text { Sosyal medya kullanmadan önce çevrem } \\
\text { tarafından kınanırım diye estetik işlem } \\
\text { yaptırmaya çekiniyordum }\end{array}$ & .485 & .740 & & \\
\hline M10 & $\begin{array}{l}\text { Sosyal medya ile birlikte estetik cerrahların ve } \\
\text { estetik operasyonların/işlemlerin ulaşılabilir } \\
\text { olduğunu düşünüyorum }\end{array}$ & & & .842 & \\
\hline M9 & $\begin{array}{l}\text { Sosyal medya ile birlikte estetik işlem konusunda } \\
\text { diğer kişilerle rahatça fikir alış verişinde } \\
\text { bulunabiliyorum }\end{array}$ & & & .718 & \\
\hline M2 & $\begin{array}{l}\text { Bedenimde bazı yerleri değiştirdiğimde daha } \\
\text { mutlu, güzel, çekici olacağıma inanıyorum }\end{array}$ & & & & .840 \\
\hline M13 & $\begin{array}{l}\text { Daha çekici, güzel ve genç görünmek için estetik } \\
\text { işlem yaptırmanın gerekli olduğuna inanıyorum }\end{array}$ & .453 & & & .617 \\
\hline M18 & $\begin{array}{l}\text { Sosyal medya kullanmaya başladıktan sonra } \\
\text { estetik işlemlerin fiziksel ve ruhsal sağlığım için } \\
\text { gerekli olduğunu düşünüyorum }\end{array}$ & & & 405 & .558 \\
\hline
\end{tabular}

Tablo 9'da yer alan faktör yük değerleri büyükten küçüğe doğru sıralanmıştır. Buradaki yük değerleri maddelerin alt boyutlarla olan bağlantısını ortaya koyan katsayılardır ve faktörlerin oluşmasına katkı sağlarlar. Araştırmada alt kesme noktası olarak ",40" kabul edilmiştir. Buna göre Tablo 5 incelendiğinde, 8 maddeden oluşan birinci faktöre ait yük değerlerinin ,722 ile ,566 arasında, 3 maddeden oluşan ikinci faktöre ait yük değerlerinin ,897 ile ,740 arasında, 2 maddeden oluşan üçüncü faktöre ait yük değerlerinin ,842 ile, 718 arasında ve yine 3 madden oluşan dördüncü faktöre ait yük değerlerinin ise ,840 ile ,558 arasında değiştiği görülmektedir.

Faktör analizine göre, ölçme aracında yer alan 5, 6, 14, 3, 11, 4, 8, 7 maddeler, birinci boyutu oluşturmakta olup, bu maddelerin tamamının "ihtiyaç" ile ilgili olduğu görülmektedir. Ölçme aracındaki 16, 17, 15 maddeler ikinci boyutu oluşturmakta olup, içerikleri incelendiğinde, 
tamamının "aleniyet" ile ilgili olduğu görülmektedir. Ölçme aracındaki 9, 10 maddeler üçüncü boyutu oluşturmakta olup, içerikleri incelendiğinde, tamamının "ulaşılabilirlik" ile ilgili olduğu görülmektedir. Ölçme aracındaki 2, 13, 18 maddeler dördüncü boyutu oluşturmakta olup, içerikleri incelendiğinde, tamamının "görünürlük" ile ilgili olduğu görülmektedir.

Katılımcıların verdikleri cevaplara göre ortaya çıkan faktörlerin toplam skor puanları ve aritmetik ortalamaları Tablo 10' da verilmiştir.

Tablo 10. Faktörlerin Ortalama Puanları ve Toplam Skorları

\begin{tabular}{|l|l|l|l|l|}
\hline & Ihtiyac & Aleniyet & Ulasılabilirlik & Görünürlük \\
\hline Ortalama & 1,91 & 1,56 & 3,01 & 2,46 \\
\hline Toplam & 221,35 & 181,32 & 350,0 & 285,82 \\
\hline
\end{tabular}

Ortaya çıkan faktörlerin toplam puanları ve ortalamaları dikkate alındığından en fazla puanın "ulaşılabilirlik" boyutuna ait olduğu görülmektedir. Katılımcılar bu boyut ile ilgili maddelere kardşı daha olumlu ve katılımcı fikir beyan etmişlerdir. Sosyal medya ile birlikte hem estetik uzmanlarına hem de estetik operasyon geçiren diğer kişilere ulaşımın kolaylaştığı sonucuna varılabilir. Diğer yüksek puana sahip faktörün ise "görünürlük" olduğuna ulaşılmıştır. Katılımclar daha genç ve çekici görünmenin onları daha iyi hissettirdiğini, sosyal medyanın da görünür olmalarında olumlu rol oynayarak katılımcıları rahatlattığı ifade edilmiştir. Hem ortalama puan hem de toplam puan bazında aleniyet boyutu en düşük puana sahiptir. Katılımcılar aleniyet boyutu ile ilgili maddelere genellikle katılmamaktadır. İlgili maddeler incelendiğinde, katılımcılar sosyal medya kullanmadan öncesinde de estetik işlemlerin gizleme ihtiyacı hissetmediklerini, çevrelerinden çekince duymadıklarını ifade etmişlerdir.

Sosyla medya ile birlikte estetik işlem ya da operasyon yaptırmanın belli bir sınıfa ait olmadığı, estetik cerrahların ve bu uygulamaların herkes tarafından ve kolaylıkla ulaşılabilir olduğu algısı oluşmuştur. Ankete katılanlar sosyal medya ile birlikte daha kusursuz görünme ihtiyacı duyduklarını ifade etmişlerdir. Photoshop gibi işlemlerle fotoğraflarında kusursuz bir görünüme ulaşan kullanıcılar, kusursuz görünme arzusunu fiziki dünyaya da taşıma arzusu duymaktadır. Sosyal medya ile estetik işlemlerin ulaşılabilirliği algısı, sosyal medya ile birlikte daha kusursuz görünme arzusuna ulaşma ve bunu fiziki dünyaya da taşıma arzusuna ulaşmayı da kolaylaştırmıştır. Dolayısıyla sosyal medya bu kusursuz görünüme ulaşmanın kolaylığını ve tüm sosyoekonomik sınıflar için mümkün olduğunu ortaya çıkarmıştır.

Çalışmaya katılanların verdikleri cevapların normal dağılım gösterip göstermediğini test etmek için yapılan normallik testlerinin sonuçları aşağıda verilmiştir. 


\section{Normalilik Testleri}

\begin{tabular}{|c|c|c|c|c|c|c|}
\hline & \multicolumn{3}{|c|}{ Kolmogorov-Smirnova } & \multicolumn{3}{|c|}{ Shapiro-Wilk } \\
\hline & Statistic & df & Sig. & Statistic & $\mathrm{df}$ & Sig. \\
\hline Yaş & 150, & 116 & 000 & ,929 & 116 & ,000 \\
\hline Cinsiyet &, 517 & 116 &, 000 & 408 & 116 & ,000 \\
\hline Eğitim Durumunuz & ,344 & 116 & , 000 & ,783 & 116 & ,000 \\
\hline Medeni Durumunuz & 411 & 116 & 000 & 608 & 116 & ,000 \\
\hline $\begin{array}{l}\text { Aylik Ortalama } \\
\text { Geliriniz (TL) }\end{array}$ & Şahsi,325 & 116 & ,000 & ,748 & 116 &, 000 \\
\hline $\begin{array}{l}\text { Sosyal medya kulla } \\
\text { sıklığınız? }\end{array}$ & lanma,252 & 116 &, 000 & 864 & 116 &, 000 \\
\hline
\end{tabular}

a. Lilliefors Significance Correction

Araştırmaya katılanların yaş, cinsiyet, eğitim durumu, aylık gelir ve sosyal medya kullanım sıklıklarının normal dağılım gösterip göstermediklerine bakıldı̆̆ında anlamlılık değerlerinin $(\mathrm{p}=0,0<0,05)$ olduğu gözlenmiştir. Hem Kolmogorov-Smirnov hem de Shapiro-Wilk normallik testi sonuçları benzerdir ve bu değerler verilerin normal dağılım göstermediğini ve yapılacak olan f.rklılık testlerinde non-parametrik testlerin kullanılması gerektiğini işaret etmektedir

Çalışmaya katılanların verdikleri cevapların eğitim durumlarına göre istatistiksel olarak farklılık gösterip göstermediklerini incelemek için non-parametrik testlerden Kruskal Wallis testinin sonuçları Tablo 11'de gösterilmiştir.

Tablo 11. Eğitim Durumuna Göre Farklılık Gösteren Maddeler

\begin{tabular}{|c|c|c|c|c|}
\hline \multicolumn{5}{|c|}{ Eğitim Durumuna Göre Farklılıka,b } \\
\hline & $\begin{array}{l}\text { Sosyal } \\
\text { medya } \\
\text { kullanma } \\
\text { sıklığınız? }\end{array}$ & $\begin{array}{l}\text { Bedenimde bazı } \\
\text { yerleri } \\
\text { değiştirdiğimde } \\
\text { daha mutlu, } \\
\text { güzel, çekici } \\
\text { olacağıma } \\
\text { inanyyorum }\end{array}$ & $\begin{array}{l}\text { Sosyal } \\
\text { medya } \\
\text { kullanmadan } \\
\text { önce estetik } \\
\text { işlemlere ve } \\
\text { estetik işlem } \\
\text { yaptıranlara } \\
\text { yönelik ön } \\
\text { yargılarım } \\
\text { vardı. }\end{array}$ & $\begin{array}{l}\text { Sosyal medya } \\
\text { kullanmadan } \\
\text { önce estetik } \\
\text { operasyonların } \\
\text { günah } \\
\text { olduğunu } \\
\text { düşünürdüm }\end{array}$ \\
\hline Chi-Square & 14,401 & 13,638 & 10,521 & 9,576 \\
\hline $\mathrm{df}$ & 4 & 4 & 4 & 4 \\
\hline Asymp. Sig. & 0,006 & 0,009 & 0,033 & 0,048 \\
\hline
\end{tabular}


Çalışmada yer alan tüm maddeler arasında sadece 4 maddede eğitim durumuna göre istatistiksel olarak anlamlı bir farklılık vardır $(p<0,05)$. Çalışma kapsamında ortaya çıkan ihtiyaç, aleniyet, ulaşılabilirlik ve görünürlük gibi faktörler arasında da eğitim durumuna göre farklılık yoktur. Eğitim düzeylerine göre farklılık gösteren maddeler detaylı olarak Levene Testi ve ile incelendiğinde ortaya çıkan sonuçlar şöyle ifade edilebilir.

- Sosyal medya kullanma sıklığında ilkokul, ortaokul ve lise düzeyinde eğitim durumu olanlar lisans ve lisansüstü düzeyine göre daha fazla süre ayırmaktadır.

- Bedenlerinde bazı yerlerin değişmesiyle daha mutlu, çekici ve güzel olacağına inanlar ise ilkokul ve lisansüstü eğitim düzeylerindekiler.

- Sosyal medya kullanmadan önce estetik işlemlere ve yaptıranlara karşı ön yargısı olan grupta ise en fazla ilkokul mezunu, sırasıyla ortaokul ve lisansüstü mezunları yer almaktadır.

- Sosyal medya kullanmadan önce estetik operasyonların günah olduğunu düşünenler ise ilkokul mezunları olarak karşımıza çıkmaktadır.

Ankete verilen cevapların ve ortaya çıkan faktörlerin cinsiyetler arasında farklılık gösterip göstermediğini test etmek için Mann-Whitney U testi uygulanmıştır. Anlamlılık değeri tüm değişkenlede $\mathrm{p}=0,05$ 'ten büyük olduğu gözlenmiştir. Bu durum ankete verilen cevapların kadınlar ile erkekler arasında istatistiksel olarak farklılığın olmadığını göstermektedir.

Diğer yandan katılımcıların verdikleri cevapların medeni durumlarına göre farklılık gösterip göstermediği incelendiğinde; anlamlılık değerlerinin 0,05’ten büyük olduğu saptanmıştır. Yani katılımcıların sosyal medya ve estetik ile ilgili görüşlerinde medeni durumlarına göre farklılık bulunmamaktadır. Medeni duruma göre katılımcıların sadece eğitim durumlarında ve aylık şahsi gelirleri farklılık vardır $(\mathrm{p}=0,00<0,05)$. Evlilerin aylık şahsi gelirleri daha fazladır.

Ankete verilen cevapların aylık şahsi gelir durumuna göre farklılık gösterip göstermediğini incelemek için Kruskal-Wallis testi yapılmıştır. Verilen cevaplarda gelir durumuna göre her hangi bir değişkende farklılık görülmemiştir. 


\begin{tabular}{|c|c|c|c|c|c|c|c|}
\hline \multicolumn{8}{|c|}{ Sosyal Medya Kullanma Sıklığına Göre Farklılıka,b } \\
\hline & $\begin{array}{l}\text { Bedenimde } \\
\text { bazı yerleri } \\
\text { değiştirdiği } \\
\text { mde daha } \\
\text { mutlu, } \\
\text { güzel, çekici } \\
\text { olacağıma } \\
\text { inanıyorum }\end{array}$ & $\begin{array}{l}\text { Sosyal } \\
\text { medya } \\
\text { kullanma } \\
\text { ya } \\
\text { başladıkt } \\
\text { an sonra } \\
\text { estetik } \\
\text { işlemleri } \\
\text { merak } \\
\text { etmeye } \\
\text { ve ilgi } \\
\text { duymaya } \\
\text { başladım }\end{array}$ & $\begin{array}{l}\text { Sosyal } \\
\text { medya } \\
\text { kullanma } \\
\text { dan önce } \\
\text { estetik } \\
\text { işlemlere } \\
\text { ve estetik } \\
\text { işlem } \\
\text { yaptıranla } \\
\text { ra yönelik } \\
\text { ön } \\
\text { yargılarım } \\
\text { vardı. }\end{array}$ & $\begin{array}{l}\text { Sosyal } \\
\text { medyada } \\
\text { gördüğüm } \\
\text { sıradan } \\
\text { insanların } \\
\text { da estetik } \\
\text { işlem } \\
\text { yaptırması } \\
\text { beni } \\
\text { cesaretlendi } \\
\text { rdi }\end{array}$ & $\begin{array}{l}\text { Sosyal } \\
\text { medya } \\
\text { kullanma } \\
\text { ya } \\
\text { başladıkt } \\
\text { an sonra } \\
\text { estetik } \\
\text { işlem } \\
\text { yaptırma } \\
\text { ya karar } \\
\text { verdim. }\end{array}$ & $\begin{array}{l}\text { Sosyal } \\
\text { medya } \\
\text { kullanmay } \\
\text { a } \\
\text { başladıktan } \\
\text { sonra } \\
\text { estetik } \\
\text { işlemlerin } \\
\text { fiziksel ve } \\
\text { ruhsal } \\
\text { sağlığım } \\
\text { için gerekli } \\
\text { olduğunu } \\
\text { düşünüyor } \\
\text { um }\end{array}$ & $\begin{array}{l}\text { Görünürl } \\
\text { ük }\end{array}$ \\
\hline $\begin{array}{l}\text { Chi- } \\
\text { Squar } \\
\text { e }\end{array}$ & 13,191 & 14,989 & 15,034 & 13,298 & 19,254 & 19,256 & 20,279 \\
\hline df & 6 & 6 & 6 & 6 & 6 & 6 & 6 \\
\hline $\begin{array}{l}\text { Asym } \\
\text { p. Sig. }\end{array}$ & 0,040 & 0,020 & 0,020 & 0,039 & 0,004 & 0,004 & 0,002 \\
\hline \multicolumn{8}{|c|}{ a. Kruskal Wallis Test } \\
\hline
\end{tabular}

Çalışmada yer alan tüm maddeler arasında sadece 6 maddede sosyal medya kullanma sıklığına göre istatistiksel olarak anlamlı bir farklılık vardır $(\mathrm{p}<0,05)$. Çalışma kapsamında ortaya çıkan görünürlük faktöründe katılımcıların sosyal medya kullanma sıklıklarına göre anlamlı farklılık vardır. İstatistiksel olarak anlamlı farklılık gösteren maddeler detaylı bir şekilde incelendiğinde ortaya çıkan sonuçlar şunlardır;

- Günde ortalama 8-12 saat arasında sosyal medyada yer alanlar(mean rank=83,0) diğer kullanıcılara göre bedenlerinde bazı yerleri değiştiğinde daha mutlu, güzel, çekici olacağına inanmaktadırlar.

- Günde ortalama 2 saatten az sosyal medyada vakit geçirenler (mean rank=77,9) diğer katılımcılara göre daha fazla sosyal medya kullanmaya başladıktan sonra estetik işlemleri merak etmeye ve ilgi duymaya başladığını ifade etmişlerdir.

- Günde ortalama 12 saatten fazla sosyal medyada yer alanlar diğer kişilere göre daha fazla (mean rank=95,6) sosyal medya kullanmadan önce estetik işlemlere ve estetik işlem yaptıranlara yönelik ön yargıları olduğunu ulaşılmıştır. . 
- Günde ortalama 8-12 saat arası sosyal medyada vakit geçiren katılımcılar sosyal medyada görülen sıradan insanların da estetik işlem yaptırmasının kendilerini cesaretlendirdiği konusunda ön sıradadır (mean rank=78).

- Günde ortalama 2 saatten az sosyal medyada bulunanlar diğer kullanıcılara göre sosyal medya kullanmaya başladıktan sonra estetik işlem yaptırmaya karar verdiğini ifade etmişlerdir(mean rank=79,2).

- Haftada birkaç kez sosyal medya platformlarını kullananlar ile günde 8-12 saat arasında sosyal medyada vakit geçirenler diğer katılımcılara göre (mean rank=86) “sosyal medya kullanmaya başladıktan sonra estetik işlemlerin fiziksel ve ruhsal sağlı̆̆ için gerekli olduğunu" düşünmektedirler.

- Görünürlük boyutu, katılımcıların sosyal medya kullanma sıklığına göre farklılık göstermektedir. Ankete katılanlardan günde ortalama 8-12 saat arasında daha fazla iken (mean rank= 88,5) süre azaldıkça ortalama puan azaldığı gözlenmiştir. Estetik işlemlerin daha genç ve güzel görünmelerinde önemli rolü olduğu ve sosyal medyanın görünür olmakta rolünün olduğuyla ilgili maddeleri bünyesinde barındıran görünürlük boyutuna yönelik günlük ortalama daha fazla süre sosyal medyada vakit geçirenler daha olumlu yaklaşmaktadırlar.

\section{Sonuç}

Sosyal medyanın yaygınlaşmasıve selfy modası ile birlikte diş görünüş önem kazanmış ve kusursuz bir görüntü önem kazanmıştır. Sosyal medya ile birlikte artık herkes takipçi sayısı oranında bir ünlü gibi hissetmeye, adeta sahneye, ekran önüne çıkarcasına görüntüsüne önem vermeye başlamıştır. Kullanıcılar kusursuz görünüm için photoshop gibi uygulamalardan yardım almış, bu kusursuzluğu fiziki hayatlarına da taşımak üzere estetik işlemlere başvurmaya başlamıştır. Sosyal medya daha önce ulaşılmaz ve sadece belli sosyo-ekonomik sınıflara ait olduğu düşünülen pek çok şey artık her sosyal statü ve ekonomik sınıftan kimseler için ulaşılabilir hale getirmiştir. Estetik işlem uygulama ve uygulatma da yine sosyal medyanın yaygınlaşmasıyla birlikte artık herkesin ulaşabildiği, sıradan bir insanın da öğle yemeği arasında gidip yaptırdığı bir işleme dönüşmüş, kişiler için bir ihtiyaç halini almıştır.

Kullanıcılar sosyal medyada plastik cerrahların, estetisyenlerin tanıtımları, bu işlemi yaptıran kendi gibi ünlü ve üst sosyo ekonomik sınıftan olmayan insanları gördükçe de bu işlemlerin ulaşılabilir olduğuna hükmetmiştir. Dolayısıyla bir kullanıcı sosyal medyada ne kadar çok vakit geçiriyorsa görünümüne de o kadar önem vermekte ve estetik işlem yaptırma algısı da buna bağlı olarak şekillenmektedir.

Geniş bir demografik yelpazede 116 kişi ile online olarak gerçekleştirilen anket sonucunda sosyal medyayı yoğun olarak kullanan kişilerin daha estetik görünmek istedikleri ortaya 
çıkmıştır. Yine ankette dikkat çeken bir diğer nokta ise eğitim durumu lise ve altı olanlarla lisansüstü olanların benzer cevapları vermiş olduklarıdır. Yaş aralığına bakıldığında lise ve altı eğitime sahip olanların çoğu 15-18 yaş aralığında sosyal medyayı aktif olarak kullanan bireyleridir. Lisansüstü eğitime sahip denekler ise yine sosyal medyayı yoğun olarak kullanan dolayısıyla yine kusursuz bir görünüme sahip olmak isteyen kullanıcılar grubu içerisindedir.

Araştırmada ortaya çıkan en önemli sonuç sosyal medyanın estetik işlemleri herkesin yaptırabileceği ulaşılabilir işlemler olarak kullanıcıların zihninde algısal bir değişim gerçekleştirmiştir. Lise ve lisansüstü kullanıcılar dışında kalan kullanıcılar estetik işlem yaptırmayı düşünmediklerini dile getirmişlerdir. Bu bağlamda da araştırma sosyal medya kullanım oranıyla estetik işlem yaptırmayı ihtiyaç olarak görme arasında doğrusal bir bağlantı olduğunu ortaya koymuştur.

\section{KAYNAKÇA}

Aktaş, S. (2014). Medyanın Kadın Estetiği Üzerine Etkileri Ve Ebenin Rolü. Anadolu Hemşirelik ve Sağlık Bilimleri Dergisi. 17:3. 89-97

Araslı, O. (2017) Medyadan "Estetik-Güzellik" Uygulamalarına "Merdiven üstu" Bir Bakış: “Adana'daki Sahte Hakkındaki Haberlerin Değerlendirmesi. Atatürk İletişim Dergisi Sayı 14. Sağlık İletişimi Özel Sayı 61-80

Atik, D. \& Örten T. (2008). Beden İmgesini Oluşturan Sosyal ve Kurumsal Faktörler ve Bu İdealin Bireyler Üzerindeki Etkileri. Edebiyat Fakültesi Dergisi 25(1):17-35.

Baudrillard. J. (2001). Baştan Çıkarma Üzerine. (Ayşeguil Sönmezay çev). İstanbul: Ayrıntı Yayınları

Bauman. Z. (2001). Parçalanmış Hayat. (İsmail Türkmen çev). İstanbul: Ayrıntı Yayınları

Foucault. M.(1992) Hapishanenin Doğuşu. Mehmet Ali Kılıçbay (çev), Ankara: İmge Kitabevi Yayınları

Işık, E, (1998), Beden ve Toplum Kuramı. İstanbul: Bağlam Yayınları

Işık. S. (2008). Estetik Beden Teröru: 11.4.2019 tarihinde http://www.derindusunce.org adresinden edinilmiştir.

Köse, H. (2011). Tüketim Toplumunda Bir “Sosyal Beden” Kurgusu Olarak Kadın. Selçuk Illetişim Dergisi, 6, 4, 76-89

Odabaş, S. (2008). Medyada Beden Politikalarının Temsili “Güzelliğin On Para Etmez Şu Estetik Cerrahlar Olmasa". Kuiltür ve İletişim 1(1):53-72.

Örsel, S.; Canpolat, I.B.; Akdemir, A. \& Özbay M.H.(2004). Diyet Yapan ve Yapmayan Ergenlerin Kendilik Algısı, Beden İmajı ve Beden Kitle İndeksi Açısından

Karşılaştırılması. Tü̈k Psikiyatri Dergisi 15(1):5-15. 
Sabah Gazatesi (02.05.2017). Son günlerin en moda estetik uygulamasını yaptı ama şimdi çok pişman. 12.04.2019 tarihinde https://www.sabah.com.tr/yasam/2017/05/02/son-gunlerin-en-modaestetik-uygula-masini-yapti-ama-simdi-cok-pisman adresinden edinilmiştir

Sarı, E. (2016). “Kliniğimize Başvuran Rekonstruiktif ve Estetik Hastaların Sosyokuiltürel Özellikleri ve Memnuniyet Seviyeleri". Türk Plastik, Rekonstrüktif ve Estetik Cerrahi Dergisi /Turk J Plast Surg 24(2): $76-82$

Show TV Ana Haber 01.10.2019 tarihinde https://www.youtube.com/watch?v=QUUmHyQVztc adresinden edinilmiştir

Silverman. K. (2006). Görü̈ü̈ Dünyanın Eşiği. (Aylin Onacak çev). İstanbul: Ayrıntı Yayınları

Tiggemann, M. \& Miller, J. (2010). The Internet and Adolescent Girls' Weight Satisfaction and Drive for Thinness. Sex Roles 63(1-2):79-90.

Twenge, J. M. \& Campbell, W. K. (2010), Asrın Vebası: Narsisizm İlleti. (Çev. Özlem Korkmaz). İstanbul: Kaknüs Yayınları

Yetişken H. (1998). Estetiğin ABC'si. 1.Baskı. İstanbul: Kabalcı Yayınevi 